\title{
EYE-HAND PREFERENCE DISSOCIATION IN OBSESSIVE-COMPULSIVE DISORDER AND DYSLEXIA
}

\author{
Marilena Occhini Siviero', Eliana Oliveira Rysovas' ${ }^{1}$, Yara Juliano², \\ José Alberto Del Porto ${ }^{3}$, Paulo Henrique Ferreira Bertolucci ${ }^{1}$
}

\begin{abstract}
Dyslexia may be a development disturbance in which there are alterations in visual-spatial and visual-motor processing, while obsessive-compulsive disorder $(O C D)$ is a psychiatric disease in which there are alterations in memory, executive function, and visual-spatial processing. Our hypothesis is that these disturbances may be, at least partially, the result of a crossed eye and hand preference. In the present study 16 controls, 20 OCD (DSM-IV criteria) and 13 dyslexic adults (Brazilian Dyslexia Association criteria) were included. All had a neurological examination, the Yale-Brown scale for obsessive-compulsive symptoms application and the Zazzó evaluation for laterality, abridged by Granjon. Results showed a right hand preference for $100 \%$ of controls, $84.6 \%$ of dyslexics, and $75 \%$ of OCD patients and a right eye preference for $73.3 \%$ of controls, $69.2 \%$ of dyslexics, and $35 \%$ of OCD patients. The left eye preference was significantly higher in OCD when compared with the two other groups $(p=0.01)$ and the left hand preference of OCD patients $(25 \%)$ was also significant when compared to Brazilian population (4\%) or British population (4.5\%). It is possible that this crossed preference may be partially the reason for visual-spatial and constructive disturbances observed in OCD.
\end{abstract}

KEY WORDS: obsessive-compulsive disorder, dyslexia, eye preference, laterality, handedness, procedural memory.

\begin{abstract}
Dissociação da preferência ocular e manual em pacientes com transtorno obsessivo-compulsivo e dislexia
RESUMO - A dislexia pode resultar de distúrbio do desenvolvimento e apresenta alterações no processamento visuo-espacial e visuo-motor, enquanto o transtorno obsessivo compulsivo (TOC) é uma alteração psiquiátrica na qual podem ocorrer alterações de memória, função executiva e visuo-espacial. Nossa hipótese é que parte destes distúrbios pode decorrer da preferência ocular e manual cruzadas. Foram avaliados 16 indivíduos normais, 20 pacientes com TOC, (critérios da DSM-IV) e 13 adultos disléxicos (critérios da Associação Brasileira de Dislexia). Todos passaram por exame neurológico, avaliação de sintomas obsessivos-compulsivos pela escala Yale-Brown e pela bateria para avaliação da lateralidade de Zazzó versão reduzida de Granjon. Os resultados mostraram a preferência pela mão direita de $84,6 \%$ nos disléxicos, $100 \%$ nos normais e $80 \%$ em TOC. A preferência ocular pelo olho direito foi de $69,2 \%$ nos disléxicos, $73,3 \%$ nos normais e apenas 35\% nos TOC, com significância de $p=0,01$ quando comparada aos outros dois grupos.A preferência da mão esquerda pelo grupo de pacientes com TOC (25\%) foi também significante quando comparada com os resultados da população brasileira em geral (4\%) ou da população inglesa (4,5\%). É possível que esta dominância cruzada seja responsável, em parte, pelas dificuldades visuo-espaciais e construcionais observadas no TOC.
\end{abstract}

PALAVRAS-CHAVE: transtorno obsessivo compulsivo, dislexia, preferência ocular, lateralidade, preferência manual, memória procedural.

Attention deficits and hyperactivity disorder (ADHD) in children have been related to obsessivecompulsive disorder (OCD) in adults, but the attention deficit can also be present in some dyslexic children. ADHD is related to the spectrum of movement disorders as Tourette syndrome and $\mathrm{OCD}^{1}$. It is known that OCD subjects have impairment in visual-spatial skills ${ }^{2-10}$ related to the right hemisphere, and dyslexics are impaired in writing and reading, preponderantly a left hemisphere task'.
As dyslexics sometimes have a cross-dominance of hand-eye-foot, we became interested in knowing which could be OCD laterality. For the assessment of laterality there are some questionnaires, including Edinburgh Handedness Inventory ${ }^{12}$ for adults, in which subjects are asked to indicate their preferred hand for writing, drawing, throwing, cutting with scissors or brushing. However, we wanted to acced laterality through behavioral tasks, observing while the patient is performing the action and the time

Federal University of São Paulo School of Medicine, São Paulo SP, Brazil: 'Department of Neurology and Neurosurgery; ${ }^{2}$ Department of Mental Health; ${ }^{3}$ Department of Psychiatry. This research was supported by FAPESP (grant 98/04496-9 to MOS).

Received 26 July 2001, received in final form 12 November 2001. Accepted 14 November 2001. 
spended to do, as assessed by Zazzó ${ }^{13}$ with children. When questionnaires are used, conscious processes are acceded with the interference of declarative memory, and they could not be the same as when we are performing the task. The performance by the repetition of motor tasks, is a procedural approach with non-conscious ${ }^{14}$ processes. We wanted to observe implicitly which hand, eye or foot would be used by OCD patients. Besides the impairment in visualspatial skills, OCD patients are also impaired in executive tasks ${ }^{2,7,10,15-20}$. Merckelbach et $\mathrm{al}^{21}$ applying questionnaires in patients with anxiety disorders found $83 \%$ of right hand dominance, $10 \%$ of left hand dominance and $6.5 \%$ with ambidextricity, but without assessment of eye or foot preference. Annett ${ }^{22}$ suggests a theory of the origin of hand preference involving three factors: a) an accidental variation in the development of the two sides of the body; b) a systematic bias to the right hand in man, also called the genetic theory of with the right shift that predicts until $12.5 \%$ of left handedness and c) sociocultural factors affecting the expression of left preference.

In none of these studies we found a relation of eye preference with psychiatric disorders. We are not aware of any work to assess hand-eye-foot dominance in $O C D$ with performance tasks measuring the time to execute a manual task.

The objective of this study was to evaluate eye and hand preference in controls, OCD and dyslexics, with the hypothesis that OCD patients could show a reverse pattern of laterality when compared with dyslexics.

\section{METHOD}

\section{Subjects}

There were two experimental groups, one with 13 dyslexic adults, diagnosed by the Brazilian Association of Dyslexia accordingly with international criteria and another with 20 OCD patients, diagnosed by DSM-IV (APA, 1993) criteria by a psychiatrist. As a comparison group, 16 healthy controls were included, without neurological or psychiat- ric disordes, matched by gender, age and education. (Table 1).The study was previously submitted and approved by the Ethic Committee on the Federal University of São Paulo, accordingly with international guidelines on research in humans.

\section{Measures}

Questionnaire - The Yale Brown Obsessive and Compulsive Scale ${ }^{23}$ was applied to the three groups.

Assessment of laterality - We applied the reduced version of Nadine Galifret Granjon , in Zazzó scale ${ }^{12}$ for testing dominance of hand, eye and foot. For the assessment of hand preference were used 32 cards, by distributing the cards one up to the other 3 times with the right hand and 3 times with the left hand. The time is measured by a chronometer and pursued to the quotient of laterality, calculated through the equation: laterality=left hand time - right hand time/ better time. The behavioral tasks included in yield a laterality quotient that ranges from +1 to -1 through 0 for equal use of the two hands. Positive ranges leads to right handedness and negative ranges to left handedness.

For the sighting task we used a paper with $25 \mathrm{~cm} \times 15$ $\mathrm{cm}$ with a hole in the center of $0.5 \mathrm{~cm}$ diameter and a kaleidoscope or a visual slide display unit. In these tasks we observed which eye the individuals would prefer.

For foot assessment we used a piece of wood and a ball. As made in the other assessment there were an odd number of tasks and the frequency of the use determined the right or left preference.

\section{Statistical method}

Statistical procedures, available in the SPSS Version 7.5 package, were used in data analysis. The Pearson Chi Square test was applied to locate significantly differences between observed and expected frequencies among the three groups. Cochran test ${ }^{24,25}$ was used to examine the agreement of hand, eye and foot laterality within each group. A McNemar test was applied to evaluate the significance of the preference of hand and eye, for the OCD group. Binomial test was used to compare the mean of preferred hand in $O C D$ and the mean of general population.

We fixed in 0.05 or $5 \%(\alpha<0.05)$ as the level for rejection of the null hypothesis.

Table 1. Study samples with demographic data.

\begin{tabular}{|c|c|c|c|c|c|c|c|c|c|}
\hline \multicolumn{10}{|c|}{ Means } \\
\hline & $\mathrm{N}$ & Male & Female & School & Std. dev. & Age & Std. dev. & YBOCS & Std. dev. \\
\hline OCDs & 20 & 8 & 12 & 10 & 3 & 32 & 12 & 16 & 6 \\
\hline Controls & 16 & 8 & 8 & 11 & 5 & 42 & 17 & 3 & 2 \\
\hline Dyslexics & 13 & 7 & 6 & 12 & 2 & 37 & 11 & 2 & 2 \\
\hline
\end{tabular}


Table 2. Frequencies of hand, eye and foot preference.

\begin{tabular}{|c|c|c|c|c|c|c|c|c|c|c|}
\hline \multirow[b]{2}{*}{ Groups } & & \multicolumn{2}{|c|}{ Hand } & \multicolumn{2}{|c|}{ Eye } & \multicolumn{2}{|c|}{ Foot } & \multirow[b]{2}{*}{ Total } & \multirow[b]{2}{*}{$\mathrm{Q}$} & \multirow[b]{2}{*}{ Significance } \\
\hline & & Right & Left & Right & Left & Right & Left & & & \\
\hline \multirow[t]{2}{*}{ Dyslex. } & $\mathrm{N}$ & 11 & 2 & 10 & 3 & 10 & 3 & 13 & 0.75 & NS \\
\hline & $\%$ & 84.6 & 15.4 & 64.2 & & 76.9 & & 100 & & \\
\hline \multirow[t]{2}{*}{ Controls } & $\mathrm{N}$ & 16 & 0 & 12 & 4 & 16 & 0 & 16 & 8 & $p=0.05$ \\
\hline & $\%$ & 100 & & 75 & 25 & 100 & & 100 & & \\
\hline \multirow[t]{2}{*}{ OCD } & $\mathrm{N}$ & 15 & 5 & 7 & 13 & 16 & 4 & 20 & 12.5 & $p=0.01$ \\
\hline & $\%$ & 75 & 25 & 35 & 65 & 80 & 20 & 100 & & \\
\hline \multicolumn{2}{|c|}{ Chi square $=$} & 3.27 & & 6.33 & & 3.78 & & & & \\
\hline \multicolumn{2}{|c|}{ Significance } & NS & & $p=0.05$ & & NS & & & & \\
\hline
\end{tabular}

\section{RESULTS}

The lateral preference: hand, eye, and foot using Cochran (Q) to study variables variance and the Chi Square were used for comparison between the 3 groups and the results are shown in Table 2.

Right hand and left eye preference were significantly more common for OCD group (Table 3 ). In the other groups we did not found a significant difference in the preference of hand and eye.

As ambidextricity is $0.34 \%$ in normals, we did not find any subjects with this dominance.

While our results of right eyedness are similar to those of the general population - 60 to $70 \%{ }^{26}, 67$ to $72 \%{ }^{27}, 88 \%^{28}$ for dyslexics and controls, the $35 \%$ found in OCD are significantly below these percentages. The preference for using right foot, of $80 \%$ to $90 \%$ in the general population is comparable to that observed in this study, but in relation to the handedness, the $25 \%$ of left manual dominance in OCD is significantly higher than the $4 \%$ found in Brazilian population ${ }^{29}$ or the $4.5 \%$ found in the general population $^{30}$

\section{DISCUSSION}

The visual system is organized in such a way that each eye sends information to both hemispheres, from the different halves of the retina, so eye preference is not a question of preferential use of one hemisphere, but that preference leads to a higher velocity of information processing if the stimulus is a non letter (iconic stimulus).

The left hemisphere usually processes letters and language and the use of the right eye will benefit in velocity those subjects with impairment in processing this type of stimulus. The choice of eye prefer-
Table 3. Distribution of responders in OCD group.

\begin{tabular}{lccc}
\hline Hand & Eye - Right & Eye - Left & Total \\
\hline Right & 6 & $9^{*}$ & 15 \\
Left & $1^{*}$ & 4 & 5 \\
Total & 7 & 13 & 20 \\
\hline
\end{tabular}

McNemar test was significant for the combinations left-hand and right eye, and right-hand and left-eye.

ence, usually done in childhood, will be a compensatory strategy or will it be done casually? We noticed that impairments in visual-spatial and constructional abilities of some OCD patients might be related to their eye preference. The cross dominance (left eye, right hand) has been related to better performance for baseball players, but a recent study ${ }^{31}$ did not find statistically significant differences between dominance patterns and batting average in players with crossed dominance or with the uncrossed dominance (right hand, right eye). However, it was shown that players with crossed dominance have an average of batting of 0.251 and with uncrossed dominance have an average of batting of 0.271 and ERAs (earned runs average) better than players with uncrossed dominance. Coren $\&$ Duncan $^{32}$ found that natural eye dominance behavior is highly resistant to change and sight dominance reflects a form of sensory or sensory motor laterality, which is independent from the refractive quality of the visual input.

Soft neurological signs are reported as more common in $\mathrm{OCD}^{33-36}$ a finding that could suggest a subtle dysfunction in central nervous system and could be one reason for change from normal function, i.e., for crossed preference. In our sample only 2 sub- 
jects displayed this kind of alteration (both with minor coordination and strength asymmetry). As Annett theory predict, it seems that OCD left handedness could be due to accidental variation in development or genetic factors, as seen in families with OCD.

In conclusion, this study will be expanded but we can think as a possibility that the shift to left handedness and left eye preference could be due to the necessary improvement in visual-spatial skills, impaired in OCD. This special laterality could compensate the slowness observed in OCD. We suggest that it is necessary to include, in the neuropsychological assessment, hand-eye-foot tasks to evaluate preference use.

Acknowledgements - To the Brazilian Association of Dyslexia for recruiting dyslexic patients.

\section{REFERENCES}

1. Sheppard DM, Bradshaw JL,Purcell R, Pantelis G. Tourette's and comorbid syndromes obsessive compulsive and attention deficit hyperactivity disorder: a common etiology? Clin Psychol 1999;19:531-552.

2. Aronowitz BR, Hollander E, DeCaria C, et al. Neuropsychology of obsessive-compulsive disorder: preliminary findings. Neuropsychiatr Neuropsychol Behav Neurol 1999;47:81-86.

3. Behar D, Rapoport JL, Berg CJ, et al. Computerized tomography and neuropsychological test measures in adolescents with obsessive-compulsive disorder. Am J Psychiatry 1984; 141:363-368.

4. Boone KB, Annanth J, Philpott L, Kaur A, et al. Neuropsychological characteristics of nondepressed adults with obsessive-compulsive disorder. Neuropsychiatr Neuropsychol Behav Neurol 1991;4:96-109 .

5. Cohen LJ, Hollander E, DeCaria CM, et al. Specificity of neuropsychological impairment in obsessive-compulsive disorder: a comparison with social phobic and normal control subjects. J Neuropsychiatr Clin Neurosci 1996;8:82-85.

6. Dirson S, Bouvard M, Cottraux J, Martin R. Visual memory impairment in patients with obsessive compulsive disorder: a controlled study. Psychother Psychosom 1995;63:22-31.

7. Head, Bolton D, Hymas N. Deficit in cognitive shifting ability in patients with obsessive-compulsive disorders. Biol Psychiatry 1989;25:929-937.

8. Hollander E, Cohen L, Richards M, et al. A pilot study of the neuropsychology of obsessive-compulsive disorder and Parkinson's disease: basal ganglia disorders. J Neuropsychiatr Clin Neurosci 1993;5:104-106.

9. Martinot JL, Allilaire JF, Mazoyer BM, et al. Obsessive-compulsive disorder: a clinical neuropsychological and positron emission tomography study. Acta Psychiatr Scand 1990;82: 233-242.

10. Purcell R, Maruff P, Kyrios M,Pantelis C.Cognitive deficits in obsessive-compulsive disorder on tests of frontal-striatal function. Biol Psychiatry 1998;43: 348-357.

11. Rumsey JM. Biology of developmental dyslexia. JAMA 1992;268: 912-915.

12. Oldfield RC. The assessment and analysis of handedness: the Edinburg Inventory. Neuropsychologia 1971; 9: 97-113.
13. Zazzo R, Granjon NG. Manual para o exame psicológico da criança. São Paulo: Ed.Mestre Jou, 1981.

14. Mishking M. The anatomy of memory. Scientific American 1999.

15. Abbruzzese M, Bellodi L, Ferri S, Scarone S. Frontal lobe dysfunction in schizophrenia and obsessive-compulsive disorder: a neuropsychological study. Brain Cogn 1995;27:202-212.

16. Abbruzzese M, Ferri S, Scarone S. Wisconsin Card Sorting Test performance in obsessive-compulsive disorder: no evidence for involvement of dorsolateral prefrontal cortex. Psychiatry Res 1995;58:37-43.

17. Abbruzzese M, Ferri S, Scarone S. The selective breakdown of frontal functions in patients with obsessive-compulsive disorder and in patients with schizophrenia: a double dissociation experimental finding. Neuropsychologia 1997;35:907-912.

18. Hymas N, Lees A, Bolton D, et al. The neurology of obsessional slowness. Brain 1991;114:2203-2233.

19. Swoboda KJ, Jenike MA. Frontal abnormalities in a patient with obsessive-compulsive disorder: the role of structural lesions in obsessivecompulsive behavior. Neurology 1995;45:2130-2134.

20. Veale DM, Sahakian BJ, Owen AM, Marks IM. Specific cognitive deficits in tests sensitive to frontal lobe dysfunction in obsessive-compulsive disorder.Psychol Med 1996:25:1261-1269.

21. Merckelbach $\mathrm{H}$, Corine R, Olff M. Handedness and anxiety in normal and clinical populations Cortex 1989, 25; 599-606.

22. Annett M. Handedness as a continuous variable with dextral shift: sex generation and family handedness in subgroups of left and right handers. Behav Gent 1994;24:51-63.

23. Goodman WK, Price LH, Rasmussen SA, et al. The Yale-Brown obsessive compulsive scale: I. Development, use, and reliability. Arch Gen Psychiatr 1989;46:1006-1011.

24. Siegel S, Castellani NJ Jr. Nonparametric statistics. 2 Ed. New York: MacGraw-Hill, 1988.

25. Landenna G, Marasini D. Metodi statistici non parametrici. Bologna: Ed. Il Mulino, 1990.

26. Porac $\mathrm{C}$,Coren $\mathrm{S}$.The effects of simulated refractive asymmetries on eye dominance Bull Psychonomic Soc 1977;9:269-271.

27. Dargent-Paré C, De Agostini M, Mesbah M, Della Tolas G. Foot and eye preference in adults: relationship with handedness, sex and age. Cortex 1992;28:343-351.

28. Mandal MK, Pandey G, Singh SK, Asthana HS. Degree of asimmetry in lateral preferences: eye, foot, ear. J Psychol 1991;126:155-162.

29. Brito GNO, Brito LSO,Paumgartten FJR, Lins MFC Lateral preferences in Brazilian adults: an analysis with the Edinburgh Inventory. Cortex 1989;25:403-415

30. Annett M. A classification of hand preference by association analysis Br J Psychol 1970; 61:303-321.

31. Laby DM, Kirschen DG, Rosenbaum AL, Mellman MF. The effect of ocular dominance on the performance of professional baseball players. Ophthalmology 1998;105:864-866.

32. Porac C, Coren S, Duncan P. Life-span age trends in laterality . J Gerontol 1980;35:715-721.

33. Lopez VC,Martin JJ, Lozano ML, Rodriguez PC, Roig MM, Dios FA Signos neurologicos menores en los trastornos obsesivo-compulsivos. Acta Luso-Esp Neurol Psiquiatria 1990;18:143-164.

34. Stein DJ, Hollander E, Chan S, et al. Computed tomography and neurological soft signs in obsessive compulsive disorder. Psychiatr Res 1993;50:143-150.

35. Caramelli P, Lima MA, Stip E, Bacheschi LA. Neurological examination in obsessive-compulsive disorder. Rev Paul Med 1996;114:12551258.

36. Bolton D, Raven P, Madronal-Luque R, Marks IM. Neurological and neuropsychological signs in obsessive compulsive disorder: interaction with behavioural treatment. Behav Res Ther 2000;38:695-708 